UDC 378.6

\author{
Razumeyko N. S., \\ $\mathrm{Ph} . \mathrm{D}$. in pedagogical sciences, \\ Head of Department of education and the Humanities, \\ Academy of State Penitentiary Service, Chernihiv, Ukraine; \\ Tkachenko O. G., \\ Ph.D. in juridical sciences, \\ Head of the Faculty, \\ Academy of State Penitentiary Service, Chernihiv, Ukraine
}

\title{
THE VARIETY OF BREACH OF POCTURE IN THE PERIOD OF STUDY AT SCHOOL
}

Research to study the state of posture (frontal plane) children enrolled in the CEI. In study 620 students participated in Chernihiv enrolled school-lyceum № 32. We analyzed the medical school maps and instrumental examination conducted these children qualified doctors. After instrumental examination in children was found expressed posture close to the group of patients with scoliosis I degree in 15,5\% of cases. Scoliotic deformation degree I-II met in 7, $5 \%$ of cases. To determine the objective evaluation of the results considering the etiology and pathogenesis of scoliotic disease we analyzed the distribution of patients by sex and age. And it was found that spinal curvature is more common in girls aged 12 to 15 years, with rightsided distortion curve dominates both boys and girls.

The results say that the posture and scoliosis I degree orthopedic pathology is dominant in schools. Therefore necessary to strengthen measures to prevent the progression of scoliotic deformation and its consequences.

Key words: scoliosis, scoliotic deformity, children, school, torsion, correction.

The relevance of the topic. Skeletone disorders of the spine is considered to be one of the most complex defects of the musculoskeletal system of man. Scoliosis is called the biological tragedy of mankind. According to the statistics of scientists of Europe, in the CIS countries - almost $98 \%$ of the kids turns this pathology. When manifestations of scoliosis, there are violations not only of the functions of the musculoskeletal system, but also the emergence and development of negative changes in the functioning of internal organs, cardiovascular, respiratory, and nervous systems, which primarily process-related pathological curvature of the spine.

Currently in Russia, the issue of control, diagnostics and metering of pathology in schoolchildren with scoliotic deformity continue to be studied and developed. Meanwhile, early detection, treatment and 
prevention of postural disorders and scoliosis is an important task of society and state.

The article aims to investigate the state of posture of children in the entire school.

Analysis of previous studies. The most common diseases among children are the manifestation of non-fixed changes of musculoskeletal system, namely the violation of posture and scoliosis.

Correct posture is an important object of observation of various Sciences. However, only in the system of physical culture the most thoroughly investigated all aspects of correct posture.

Analysis of literature shows that in recent years the issues of physical development of schoolchildren and in particular posture and curvature of the spine in the spotlight. Many contemporary authors (G. S. Arabs, N. T. Belyakova, Y. S., Weinbaum, A. D., Dubovy, F. M. Lopatin N. And. Nosko, N. And. Fonarev and others) devote their work problems of physical development of children.

But among experts there is no General idea, like the nature and dynamics of posture and especially the beginning of the discovery of the violation during the entire schooling.

The presentation of the material. Scoliosis is a disease characterized by the arcuate curvature of the spine in the frontal plane, combined with the torsion of the vertebrae [2, p. 289]. The presence of torsion is the main symptom of scoliosis in comparison with impaired posture in the frontal plane.

Torsion (torsio) - twisting of the vertebrae around a vertical axis, accompanied by deformation of their parts and the displacement of the vertebrae relative to each other during the whole growth period of the spine [3, p. 393].

In the upper half of the arc of curvature of the spinous processes are bent in the convex direction, in the lower - concave.

On the concave side of the scoliosis muscles and ligaments shortened, convex - strapped. Stretched muscles on the convex side developed significantly weaker than the shortened muscles on the concave side of the vertebral arch. Returned the ribs; the sternum is displaced and tilted in the concavity. Through the displacement of the ribs occurs a change in the shape of the chest. Thorax more than just deformed by scoliosis in the thoracic vertebrae region. On the convex 
side the ribs are directed obliquely down forward, the space between the ribs expanded. On the concave side the ribs are less tilted from the front and located close to each other. The blades are at different heights; in the case of scoliosis in the thoracic part of the spine of the blade also have the torsos. The pelvis is tilted with torsion around the sacrum [3, p. 402].

These structural changes lead to the disruption of cardiovascular and respiratory systems, gastrointestinal tract and other body systems. Therefore correct to speak not only about scoliosis, and scoliosis disease.

There are three degrees of the incorrect posture.

First degree is characterized by changing muscle tone. All posture defects disappear when the person straightens up. The violation is easily corrected with the systematic classes of corrective gymnastics [1, p. 15].

The second degree is characterized by changes in the ligamentous apparatus of the spine. Changes can only be corrected with prolonged classes of corrective gymnastics under the guidance of medical professionals [1, p. 15].

The third degree is characterized by persistent changes in the intervertebral cartilage and bones of the spine. Changes are not corrected caraguatay gymnastics, and require special orthopedic treatment [1, p. 16].

Scoliosis is one of the challenging problems in the theory and practice of pediatric pathology. Literature data on the prevalence of scoliosis is controversial. According to different authors, the scoliosis subject from 1 to $53 \%$ of the total child population. Such fluctuations in the indicator due to the fact that there is no uniform classification of postural disorders and scoliosis.

To create a view on the state of the posture of todays children and to reveal the dynamics of such diseases as scoliosis, we have analyzed 620 school health cards of students who are studying in Chernihiv school-Lyceum № 32. According to school medical records $75 \%$ of students have an orthopedic pathology (disturbance of posture, scoliosis, chest deformity or flat feet). After instrumental examination of these children by physicians revealed a marked disturbance of posture close to the group of patients with scoliosis of I degree in $15,5 \%$ of cases. Scoliosis deformation of I-II degree was found in 7, $5 \%$ of cases (Figure 1). 


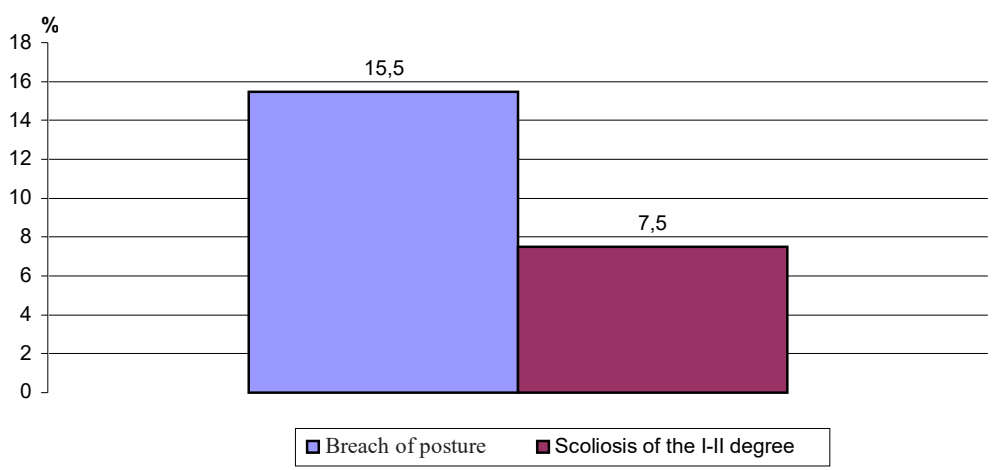

Figure 1. Frequency of violations of posture and scoliosis I-II degree instrumental examination in children of school-Lyceum № 32

To determine the objective evaluation of obtained results taking into account the etiology and pathogenesis of scoliotic disease, we analyzed the distribution of patients by sex and age. This allocation was based on the characteristics of neurohumoral maturation of the child in different period of time of growth of the organism enables us to make a correlation between early onset scoliosis and its progression, as well as for the selection of methods of posture correction (Table 1).

Table 1

The age and gender of students with incorrect posture and scoliosis i-II degree Floor

\begin{tabular}{|c|c|c|c|}
\hline \multirow{2}{*}{$\begin{array}{c}\text { Floor. } \\
\text { Age }\end{array}$} & \multicolumn{3}{|c|}{ The number of patients boys girls total } \\
\cline { 2 - 4 } 6-9 years & boys & girls & total \\
\hline 10-13 years & 27 & 45 & 72 \\
\hline 14-16 years & 56 & 42 & 98 \\
\hline Just & 55 & 54 & 109 \\
\hline
\end{tabular}

From table 1 it is seen that the highest frequency of the disease among schoolchildren aged 12-16 years. Subsequently, we were able to separate the children according to sex and side of the scoliotic arc, which allowed more widely to consider the mechanisms of pathogenesis of scoliotic deformation. In our study, it is revealed that the curvature of the spine is more common in girls aged 12 to 15 years, while the right-hand arc of curvature is dominated by boys and girls (Table 2). 
Table 2

The distribution of children with scoliotic disease of the regardless of the angle of scoliosis and sex

\begin{tabular}{|l|c|c|c|c|c|}
\hline \multicolumn{7}{|c|}{ The number of patients } \\
\hline \multirow{2}{*}{$\begin{array}{c}\text { Floor. } \\
\text { Age }\end{array}$} & \multicolumn{2}{c|}{$\begin{array}{c}\text { Left scoliosis } \\
\text { scoliosis }\end{array}$} & \multicolumn{2}{c|}{$\begin{array}{c}\text { Right scoliosis } \\
\text { scoliosis }\end{array}$} & \multirow{2}{*}{ Just } \\
\cline { 2 - 5 } & women & women & men & women & \\
\hline $6-9$ years & 0 & 6 & 3 & 9 & 18 \\
\hline $10-13$ years & 3 & 7 & 7 & 8 & 25 \\
\hline $14-16$ years & 8 & 10 & 13 & 17 & 48 \\
\hline Just & 11 & 23 & 23 & 34 & 91 \\
\hline
\end{tabular}

This may be important for the discussion of questions differentiated posture correction. The degree of scoliosis was diagnosed according to the classification of V. D. Chaklin (1957) depending on the angle of deformation. Girls predominated in all groups and amounted to $61,0 \%$ of the total number surveyed.

When analyzing the incidence of scoliosis in violation of posture in schoolchildren of different ages we obtained the results indicating that pupils of 1-4 classes of incorrect posture occur in $18,6 \%$ of cases, scoliosis in 6,4\% of cases; students in grades 5-8 posture are found in $25,4 \%$ of the students, scoliosis $-9,3 \%$ of cases. In grades 9-11 incorrect posture occur $22,9 \%$ of cases, scoliosis - from $17,2 \%$ of children (Figure 2).

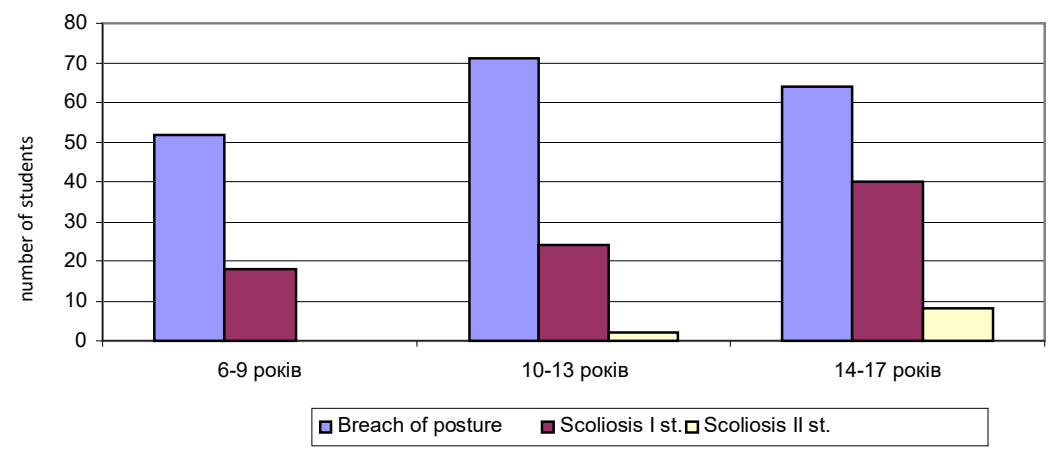

Figure 2. Distribution of children with violation of posture and scoliosis I and II

This demonstrates the dependence of the scoliotic deformation up to the age of the child, which means that during puberty the 
percentage of scoliosis becomes maximum. This fact indicates consistency of scoliotic disease, which should be considered in the diagnosis and prevention of scoliotic illness in primary degrees.

The obtained results indicate that violations of posture and scoliosis I degree are the dominant orthopedic pathology in educational institution. It is therefore necessary to strengthen measures for the prevention of progression of scoliotic deformation and its consequences.

Conclusion. In view of the foregoing, we conclude that training health physical culture, which are held in secondary schools without taking into account the relevant characteristics of posture defects are not able to eliminate various types of violations of posture and ensure their effective correction. In this regard, a differentiated approach and clearly organized work with children with violation of posture, to prevent further large-scale deformations of the musculoskeletal system in children and young people.

Prospects of further studies lie in the substantiation of practical recommendations for the differentiated use of posture correction in children in secondary schools.

\section{References}

1. Needle, G., Buryanov, O. and Klimovich, V. (2014), Traumatology and orthopedics: textbook for students. higher educational institution, new book, Vinnitsa.

2. Dvoryakovsky, I. (2003), Changes in the musculoskeletal system and their correction for posture disorders in children: kand. biological. of Sciences, Kyiv, $222 \mathrm{p}$.

3. Traumatology: textbook for students, (2006), higher education institutions: Ukrmedkniga, $528 \mathrm{p}$.

4. Laputin, A. M. (2002), "Measurement of the tone of skeletal muscle of man", Science in Olympic sports. No. 1. pp. 69-73.

5. Nosko, M., Razumeiko, N. (2009), "Modern problems of professional training of teachers of physical culture", Bulletin of Chernihiv national pedagogical University, CNPA, Vol. 67, pp. 53-55. 
Разумейко Н. С., кандидат педагогічних наук, начальник кафедри педагогіки та гуманітарних дисциплін, Академія Державної пенітенціарної служби, м. Чернігів, Україна;

Ткаченко О. Г., кандидат юридичних наук, начальник факультету пробації, Академія Державної пенітенціарної служби, м. Чернігів, Україна ВИДИ ПОРУШЕНЬ ПОСТАВИ ДІТЕЙ У ПЕРІОД
НАВЧАННЯ В ШКОЛІ

Проведено дослідження порушення постави у 620 школярів, щзо навчаються в Чернігівській школі-лічеї № 32. Проаналізовано шкільні медичні карти та проведено інструментальне обстеження иих дітей кваліфікованими лікарями. Після інструментального обстеження у дітей було виявлено виражене порушення постави, наближене до групи хворих зі сколіозом I ступеня у 15,5\% випадків. Сколіотична деформація I-II ступеня зустрічалася в 7,5 \% випадків. Для визначення об 'єктивної очінки отриманих результатів з урахуванням етіологї і патогенезу сколіотичної хвороби зроблено аналіз розподілу пацієнтів за статтю та віком. Визначено, шо викривлення хребта частіше зустрічається y дівчаток у віці від 12 до 15 років, при ц̧ьому правобічна дуга викривлення переважає як у хлопчиків, так $і$ у дівчаток. Отже, порушення постави і сколіоз I ступеня є домінуючою ортопедичною патологією в загальноосвітньому закладi. Тому необхідно посилення заходів щцодо профілактики прогресування сколіотичної деформачиї та ї̈ наслідків.

Ключові слова: сколіоз, сколіотична деформащія, діти, навчання в школі, торсія, корекиія. 